\title{
Mapping Main Structures and Related Mineralization of the Arabian Shield (Saudi Arabia) Using Sharp Edge Detector of Transformed Gravity Data
}

\author{
Ahmed M. Eldosouky ${ }^{1, * \mathbb{D}}$, Reda A. Y. El-Qassas ${ }^{2}$, Luan Thanh Pham ${ }^{3} \mathbb{D}$, Kamal Abdelrahman ${ }^{4}$ (D), \\ Mansour S. Alhumimidi ${ }^{5}$, Ahmed El Bahrawy ${ }^{6}$, Kevin Mickus ${ }^{7}$ and Haytham Sehsah ${ }^{6}$ (D) \\ check for \\ 1 Geology Department, Faculty of Science, Suez University, Suez 43518, Egypt \\ 2 Exploration Division, Nuclear Materials Authority, Maadi, Cairo 530, Egypt; redaelqassas@nma.org.eg \\ 3 Faculty of Physics, University of Science, Vietnam National University, Hanoi 334, Vietnam; \\ luanpt@hus.edu.vn \\ 4 Department of Geology \& Geophysics, College of Science, King Saud University, P.O. Box 2455, \\ Riyadh 11451, Saudi Arabia; khassanein@ksu.edu.sa \\ 5 National Center for Petroleum and Mining Technologies, King Abdulaziz City for Sciences and Technology, \\ P.O. Box 6086, Riyadh 11442, Saudi Arabia; humimidi@kacst.edu.sa \\ 6 Geology Department, Faculty of Science, Damietta University, New Damietta 34517, Egypt; \\ aelbahrawy@du.edu.eg (A.E.B.); haytham_sehsah@du.edu.eg (H.S.) \\ 7 Geology Department, Missouri State University, Springfield, MO 65897, USA; \\ kevinmickus@missouristate.edu \\ * Correspondence: Ahmed.Eldosouky@sci.suezuni.edu.eg
} updates

Citation: Eldosouky, A.M.; El-Qassas, R.A.Y.; Pham, L.T.; Abdelrahman, K.; Alhumimidi, M.S.; El Bahrawy, A.; Mickus, K.; Sehsah, H. Mapping Main Structures and Related Mineralization of the Arabian Shield (Saudi Arabia) Using Sharp Edge Detector of Transformed Gravity Data. Minerals 2022, 12, 71. https://doi.org/10.3390/ $\min 12010071$

Academic Editors: Manuel Francisco Pereira and Enrique Gomez-Rivas

Received: 29 October 2021

Accepted: 3 January 2022

Published: 5 January 2022

Publisher's Note: MDPI stays neutral with regard to jurisdictional claims in published maps and institutional affiliations.

Copyright: (c) 2022 by the authors. Licensee MDPI, Basel, Switzerland. This article is an open access article distributed under the terms and conditions of the Creative Commons Attribution (CC BY) license (https:// creativecommons.org/licenses/by/ $4.0 /)$.

\begin{abstract}
Saudi Arabia covers most of the Arabian Peninsula and is characterized by tectonic regimes ranging from Precambrian to Recent. Using gravity data to produce the lateral boundaries of subsurface density bodies, and edge detection of potential field data, a new subsurface structural map was created to decipher the structural framework controls on the distribution of gold deposits in Saudi Arabia. Moreover, we detected the relationships between major structures and mineral accumulations, thereby simultaneously solving the problem of edge detectors over complex tectonic patterns for both deeper and shallower origins. Analytic signal (ASg), theta map (TM), TDX, and softsign function (SF) filters were applied to gravity data of Saudi Arabia. The results unveil low connectivity along the Najd fault system (NFS) with depth, except perhaps for the central zones along each segment. The central zones are the location of significant gold mineralization, i.e., Fawarah, Gariat Avala, Hamdah, and Ghadarah. Moreover, major fault zones parallel to the Red Sea extend northward from the south, and their connectivity increases with depth and controls numerous gold mines, i.e., Jadmah, Wadi Bidah, Mamilah, and Wadi Leif. These fault zones intersect the NFS in the Midyan Terrane at the northern part of the AS, and their conjugation is suggested to be favorable for gold mineralization. The SF maps revealed the boundary between the Arabian Shield and Arabian Shelf, which comprises major shear zones, implying that most known mineralization sites are linked to post-accretionary structures and are not limited to the Najd fault system (NFS).
\end{abstract}

Keywords: gravity; edge detection; tectonic; Saudi Arabia; structural map

\section{Introduction}

The AS is of economic interest as it has promising potential for metallic mineral exploitation. The AS includes magmatic to late magmatic contact metamorphism, stratiform, and vein deposits [1]. Many gold (Au) occurrences and other deposits have been detected in the AS (>800); some of them are in the production stage, such as Mahd Ad Dahab, Al-Sukhaibarat, and Bulghah [1,2]. Furthermore, the base metals (copper, zinc, and lead) are delineated in some localities of the AS, for example, Al-Nuqrah, AL-Amar, and Jabal Sayid [1]. 
An important task in interpreting potential field data is to determine the location of the subsurface density or magnetic susceptibility distributions and relate these to sub-surface structures [3-7]. The edges of structures are useful in mapping boundaries for mineral and oil exploration and tectonic investigations [8-12]. Various methods can be used to detect structure edges, with most methods being based on derivatives of the source field $[13,14]$. The authors of [15] used the zero values of the first-order vertical gravity gradient to locate the boundaries of the density-differing sources. Meanwhile, [16] used the peaks of the horizontal gravity gradient to image structure boundaries, while [17] used the total gravity gradient to extract density source edges. In [18], they used the analytic signal (ASg) of the gravity gradient tensor to outline the boundaries of density sources. A limitation of the vertical, horizontal, and total gravity gradients, and the ASg gravity method, is that they have difficulty simultaneously determining boundaries of shallow and deep density sources $[19,20]$. Several methods have been developed for solving these problems, including the tilt derivative method, which is an arctan function of the ratio between the vertical and horizontal gradients [21]; the theta map (TM) method, which normalizes the horizontal gradient by the total gradient [22]; the horizontal tilt angle filter, which normalizes the absolute value of the vertical gradient by the horizontal gradient [23]. Although the latter methods can detect the edges of shallow and deep sources simultaneously, they can also produce false or secondary edges not related to actual density sources [24,25]. To overcome this drawback, [26] suggested using the tilt derivative of the horizontal gradient (TAHG) to avoid producing secondary edges, but this may reduce resolution [27,28]. Recently, [29] introduced the soft sign function (SF) filter, which is based on the second-order derivatives of the potential field data. This method effectively improves the resolution of boundary detection results while avoiding the secondary boundary issue.

In this study, we applied the ASg, TM, TDX, and SF filters to satellite gravity data from Saudi Arabia to produce a new structural map and to define the relationship between mineralization and major shear zones

\section{Geology}

Saudi Arabia is classified by two major geological features: the Arabian Shield (AS) in the west and the Arabian Shelf, east of the AS (Figure 1) [30]. The AS consists of Precambrian igneous and metamorphic rocks, divided into eight terranes (Asir, Jeddah, Afif, Ad Dawadimi, Ar Rayn, Ha'il, Hijaz, and Midyan) according to their mode of formation [31]. The ANS is part of a wider Proterozoic terrane called the Arabian-Nubian Shield that extends to Egypt, Sudan, and Eritrea [32]. Most of the lithologies are Neoproterozoic in age with scattered Archean and Paleoproterozoic lithologies. The Neoproterozoic crust results from 300 million years of tectonic crustal growth starting at $250 \mathrm{Ma}$ [32]. During these 300-million-year periods, a series of magmatic arcs, sedimentary and volcanic basins, and granitic intrusions formed during at least three continental collisions. These collisions mostly occurred as intraoceanic subduction zones within the Mozambique Ocean, formed by the breakup of Rodinia. The island arcs above them accreted to the ANS by the Cryogenian-Ediacaran convergence of cratonic blocks, where the accretion zone is at the surface as suture zones. The accretions started in the southern ANS, subsequently moved to the north, and finally terminated in the northeast ANS during the formation of Gondwana [33]. In the eastern part of the ANS, where the cessation of accretion is poorly understood, pre-EAO blocks are not recorded. The ANS continues under the Arabian Shelf or Platform. The Arabian Platform is a sequence of Paleozoic and younger sediments, mainly formed on passive margins containing up to $10 \mathrm{~km}$ of limestones and siliciclastics. The Paleozoic sequence hosts the world-famous oil and gas fields [34]. 


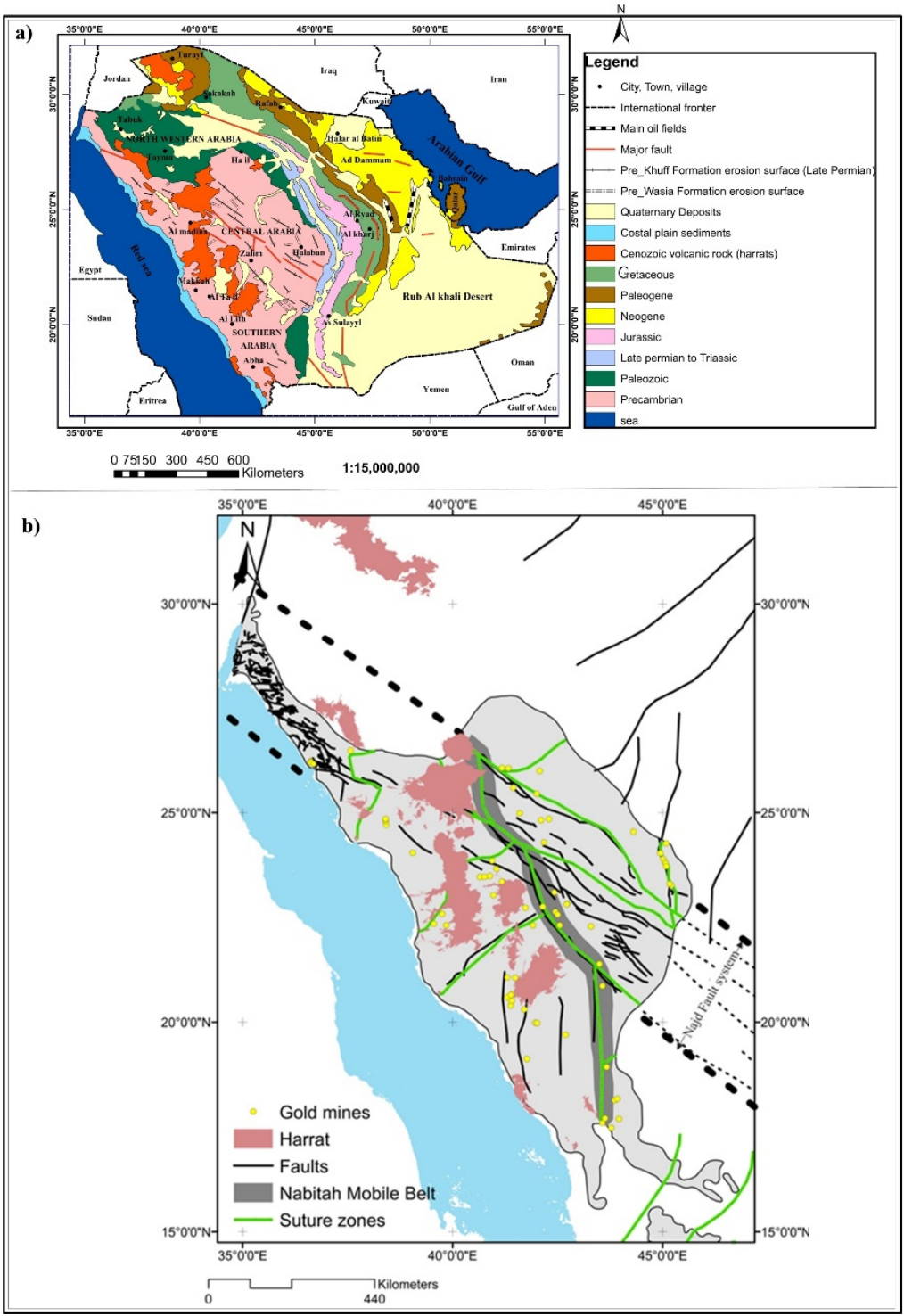

Figure 1. (a) Location and geologic map of Saudi Arabia modified after [35,36]. (b) Mineralization and structures of the Arabian shield modified from [32,33,37,38].

The ANS has been affected by the Najd fault system (NFS), which is a system of NW-trending, crustal-scale, sinistral strike-slip faults, and ductile shear zones formed during the collision between east and west Gondwana (Figure 1b) $[37,39,40]$. The NFS extends for $2000 \mathrm{~km}$, is over $400 \mathrm{~km}$ wide, and is partially covered by Cenozoic lavas and alluvium [32,41]. The NFS consists of a complex of parallel and en echelon faults with secondary structures including strike-slip, oblique-slip, thrust, and normal faults, along with folds and dike swarms. Movement along the NFS has exposed and formed core complexes, such as the Dokhan volcanics, granite plutonism, and molasse basins [37]. The Najd fault system cuts through older Neo-Proterozoic terranes and, in some cases, reactivated them. Deformation along the NFS is mainly brittle, but there is a penetrative tectonic fabric parallel to the fault zone in the southeastern ANS. The NFS consists of a complex of parallel and en echelon faults. With the termination of the major faults, secondary structures were formed, including strike-slip, oblique-slip, thrust, and normal faults, together with folds and dike swarms. Additionally, crustal-scale fault systems include N-S trending strikeslip faults in the southern AS (Asir Terrane) and the eastern ANS [32]. NE-SW trending strike-slip faults occur within western AS in the Jiddah Terrane [41]. The geophysical data, and the wells drilled in the Rub' $\mathrm{Al}$ Khali, reveal a basin situated under the Quaternary 
sand with structural evolution from the late Precambrian to the Neogene [42]. Additionally, these data displayed N-S and NW-SE trends. The Moho depth is about $40 \mathrm{~km}$ for the Rub' Al Khali area [43,44].

There are two main types of suture zones within the ANS: arc-arc sutures and arccontinent sutures. Arc-arc sutures separate juvenile terranes and include the YanbuOnib-Sol Hamed-Allaqi-Heinai suture [45,46], the Nakasib-Bir Umq suture [47,48], the Baraka-Tulu Dimtu suture [45,49], the Adola-Moyale suture [49], and the Afif terrane suture [37]. The less common arc-continent sutures separate juvenile EAO blocks from the pre-Neoproterozoic crust and include the Keraf suture to the west of the ANS [49,50].

The AS is characterized by economic importance as it contains a high potential for metallic mineral deposits. Many Au occurrences and deposits exist in the AS (>800), with some in the production stage, such as Mahd Ad Dahab, Al-Sukhaibarat, and Bulghah [1,2]. Additionally, base metal (copper, lead, zinc, and silver) occurrences have been reported in some locations of the ARS, for example, Jabal Sayid, Al-Nuqrah, and AL-Amar [1].

\section{Ore Deposits on the Arabian Shield}

Economic mineral concentrations, including Au mineralization on the ANS, can be related to three different types of tectonic settings and their host rocks [51]. The mineral deposits are partially related to the major fault systems or suture zones within the ANS [52]. Volcanogenic massive sulfides (VMS), epithermal base- and precious-metal deposits are mainly associated with volcano and sedimentary sequences. Some of the sequences have been reworked by the NFS, where some of the Au-rich VMS and syngenetic Au-poor VMS deposits were overprinted by regional tectonic deformation and Au mineralization [51]. The second type of Au mineralization is associated with carbonatize ophiolitic ultramafic rocks, which formed along the Neoproterozoic suture zones and have been found along with the Nabitah Al Amar, Di'r Um, and Yanbu suture zones [53]. The third type of Au deposit is associated with the late Neoproterozoic tectonic activity (640-610 Ma), which included granitic pluton development and volcanic units associated with these intrusions [54]. Some of these deposits are structurally controlled by the regional strike-slip faults formed after the accretion of the terranes that formed the ANS [55].

Orogenic Au (Au-bearing quartz-carbonate veins) [52] is the most common Au deposit in the ANS, with VMS Au deposits being the second most common [52]. The redistribution of $\mathrm{Au}$ within quartz-carbonate vein-type deposits requires the circulation of low salinity, high $\mathrm{CO}_{2}$ hydrothermal fluids through structurally controlled channels within maficultramafic successions [56].

The Arabian-Nubian Shield (ANS) is a fan- or flower-shaped structure of the juvenile crust, tipped-out at its southern part and expanded E-W toward the north. The ANS is accreted mainly over intraoceanic subduction zones, with the old intraoceanic subduction zones preserved at the surface as suture zones. Terrane accretions started from the southern part moving northward but terminated at the northeastern part of the ANS during the Gondwana amalgamation [33]. In the eastern part of the ANS, where the cessation of accretion is poorly understood, pre-EAO blocks are not recorded. Instead, different terranes with various geologic histories are recorded east of the ANS in Oman, which is considered a window into Indian Neoproterozoic accretionary growth [57].

Of the two main types of sutures identified in the ANS, the arc-arc sutures are the most abundant type separating juvenile terranes, including the Yanbu-Onib-Sol HamedAllaqi-Heinai suture [45,46], the Nakasib-Bir Umq suture [47,48,58-60], the Baraka-Tulu Dimtu suture [45,49], the Adola-Moyale suture [49], and the Afif terrane suture [37]. The arc-continent sutures separate juvenile EAO blocks from the pre-Neoproterozoic crust, i.e., the Keraf suture to the west of the ANS [49,50,61]. The ANS with a mantle geochemical signature is dominated by $\mathrm{Au}, \mathrm{Nb}, \mathrm{Ta}, \mathrm{U}$, and REE mineralization [37], and their redistribution to the economic grade is controlled by shear zones and fault systems.

Shear zones are intense ductile deformations that are thin relative to their lateral extent. Shear zones, similar to faults, typically show offsets of older structures, but unlike faults, 
they lack through-going brittle fractures. In practice, faults and shear zones are closely related. Many major fault structures at the Earth's surface probably connect with ductile shear zones at depth, and in the transition, it is common to find composite zones that display combinations of brittle fracture and ductile flow.

The Najd fault system (NFS) is one of the main structural features cutting through the Precambrian Arabian Shield and is an NW-SE trending complex set of crustal-scale sinistral strike-slip faults and ductile shear zones [37,39,62]. The core complex exhumation, Dokhan volcanics, younger granite plutonism, and molasse basins are the main morphotectonic units related to the Najd fault system [37]. The formation of the NFS is probably related to the E-W Gondwana collision event. As a post-accretionary fault system, it is the largest exposed Proterozoic transcurrent (strike-slip) fault system on Earth $[37,39,63]$. The NFS is between 630 and $540 \mathrm{Ma}$ (Precambrian to Lower Cambrian) and is approximately $300 \mathrm{~km}$ in width [62]. Exposure of the NFS extends for $1100 \mathrm{~km}$ inland, while the inferred buried extensions give it a total length of $2000 \mathrm{~km}$ (Figure 1). The NFS deformation is mainly brittle, but there is a penetrative tectonic fabric parallel to the fault zone in the southeastern Arabian Shield. Basement block movement along the line of the Najd has affected the Phanerozoic cover strata for more than $100 \mathrm{~km} \mathrm{SE}$ from the edge of the shield. The NFS is a complex of parallel and en echelon major faults, with curved outcrop traces that intersect or join to form braided zones. At the termination of the major faults, secondary structures are formed, including strike-slip, oblique-slip, thrust, and normal faults, together with folds and dike swarms. Local reactivation by the Tertiary Red Sea rifts is present at the termination of the NFS at the Red Sea coast [64]. The importance of the Najd fault system includes its sheer size, role in the cratonization of Gondwana, and control on the distribution of hydrothermal ore deposits $[65,66]$ and groundwater flow $[67,68]$.

Orogenic $\mathrm{Au}$ (Au-bearing quartz-carbonate veins) [37] in the Arabian Shield is the predominant mineral deposit type, but VMS Au deposits are also found and include the Jabal Say'id deposit [37]. The redistribution of $\mathrm{Au}$ into quartz-carbonate vein deposits requires the circulation of low salinity, high $\mathrm{CO}_{2}$ hydrothermal fluids through structurally controlled channels within mafic-ultramafic successions [56]. This study delineates the structural framework of the Saudi Arabian portion of the ANS that controls the distribution of orogenic $\mathrm{Au}$ and the connectivity between these pathways at different depths.

\section{Gravity Data Analysis Methodology}

In order to investigate the structural controls that helped localize ore deposits within the ANS, we employed a variety of edge detection methods for delineations in the gravity data.

The authors of [17] proposed using the maximum values of the ASg to distinguish density source edges, where the ASg is given by:

$$
\mathrm{ASg}=\sqrt{\left(\frac{\partial \mathrm{F}}{\partial \mathrm{x}}\right)^{2}+\left(\frac{\partial \mathrm{F}}{\partial \mathrm{y}}\right)^{2}+\left(\frac{\partial \mathrm{F}}{\partial \mathrm{z}}\right)^{2}} .
$$

The ASg method uses the maximum ASg values to infer the source edges. Although this method is less dependent on the source vector direction, the result is unclear for thin or deep sources [11,69].

In [22], the TM approach was introduced, which normalizes the total horizontal gradient by the ASg:

$$
\mathrm{TM}=\operatorname{acos} \frac{\sqrt{\left(\frac{\partial \mathrm{F}}{\partial \mathrm{x}}\right)^{2}+\left(\frac{\partial \mathrm{F}}{\partial \mathrm{y}}\right)^{2}}}{|\mathrm{AS}|} .
$$

The minimum values of the TM correspond to the horizontal boundaries of the potential field sources. The method can balance the anomaly amplitudes generated by density sources from different depths. However, it may produce false edges when the model simultaneously contains both positive and negative density contrasts or magnetizations [19]. 
In [23], they developed the TDX method, which is the normalization of the total horizontal gradient by the absolute value of the vertical gradient:

$$
\operatorname{TDX}=\operatorname{atan} \frac{\sqrt{\left(\frac{\partial F}{\partial x}\right)^{2}+\left(\frac{\partial F}{\partial y}\right)^{2}}}{\left|\frac{\partial F}{\partial z}\right|}
$$

The TDX method uses the maximum TDX values to outline the edges of the density sources. The method is similar to the TM method, as it can produce edges from both deep and shallow anomalies, but may produce false edges around sources $[66,70]$.

Another balanced edge detection method, introduced by [29], is called the SF filter. The filter is defined as follows:

$$
\mathrm{SF}=\frac{\mathrm{k} \times \mathrm{HG}_{\mathrm{z}}-(\mathrm{k}+2) \sqrt{\left(\mathrm{HG}_{\mathrm{x}}\right)^{2}+\left(\mathrm{HG}_{\mathrm{y}}\right)^{2}}}{\sqrt{\left(\mathrm{HG}_{\mathrm{x}}\right)^{2}+\left(\mathrm{HG}_{\mathrm{y}}\right)^{2}}+\left|\mathrm{k} \times \mathrm{HG}_{\mathrm{z}}-(\mathrm{k}+1) \sqrt{\left(\mathrm{HG}_{\mathrm{x}}\right)^{2}+\left(\mathrm{HG}_{\mathrm{y}}\right)^{2}}\right|}
$$

where $\mathrm{k}$ is a positive real number chosen by the interpreter; in this study, we used $\mathrm{k}=4$ [29]. $\mathrm{HG}_{\mathrm{x}}, \mathrm{HG}_{\mathrm{y}}$, and $\mathrm{HG}_{\mathrm{z}}$ are the $\mathrm{x}, \mathrm{y}$, and $\mathrm{z}$ gradients of the horizontal gradient $\mathrm{HG}$ of the potential field data $\mathrm{F}$, which is given by:

$$
H G=\sqrt{\left(\frac{\partial F}{\partial x}\right)^{2}+\left(\frac{\partial F}{\partial y}\right)^{2}} .
$$

The authors of [29] showed that values of $\mathrm{k}$ between 1 and 10 provide the best results. The maximum values of the SF are on the source edges, and it can detect shallow and deep edges at the same time. The disadvantage of the SF method is that it is more sensitive to noise than other methods [29]. The major advantage of the method is that it avoids false edges. However, upward continuing of the gravity data reduces the noise [29].

\section{Results}

The gravity data were obtained from the global gravity field model EIGEN6C4 [71]. The EIGEN6C4 data have a higher resolution, and their error is lower than that of EIGEN6C3 and EGM2008 [72]. The EIGEN6C4 model was created using the satellite gravity data from the DTU10, GOCE, LAGEOS, and GRACE projects and available surface gravity data. The resultant grid has a resolution of approximately $3.66 \mathrm{~km}$. Figure 2 shows the Bouguer gravity anomaly (BG) map after correcting the free-air gravity anomaly data from the EIGEN6C4 model. The BG map of Saudi Arabia (Figure 2a) shows a regional variation in the anomaly values that trend from lower anomaly values in the west to higher anomaly values in the east. The regional anomaly gradient contrasts with the thickening of the crust to the east [73], suggesting that this regional gravity anomaly gradient is due to lithological crust variations. Additionally, there are definite northwest-southeast and north-south trends in the majority of the anomalies, which can be related to the Neoproterozoic tectonic terranes and fault systems (Figure 1).

The ASg, TM, TDX, and SF filters were applied to the BG data (Figure 2a). The ASg map (Figure $2 b$ ) does not produce obvious lineaments that can be related to shallow or deep structures. Figure $2 \mathrm{c}-\mathrm{d}$ show that the TM and TDX filters generate lineaments that are intraconnected, which can complicate the interpretation process. The SF map (Figure 3) indicates a more precise delineation in terms of length and width. The SF-derived lineations are easier to interpret by visual comparison. 


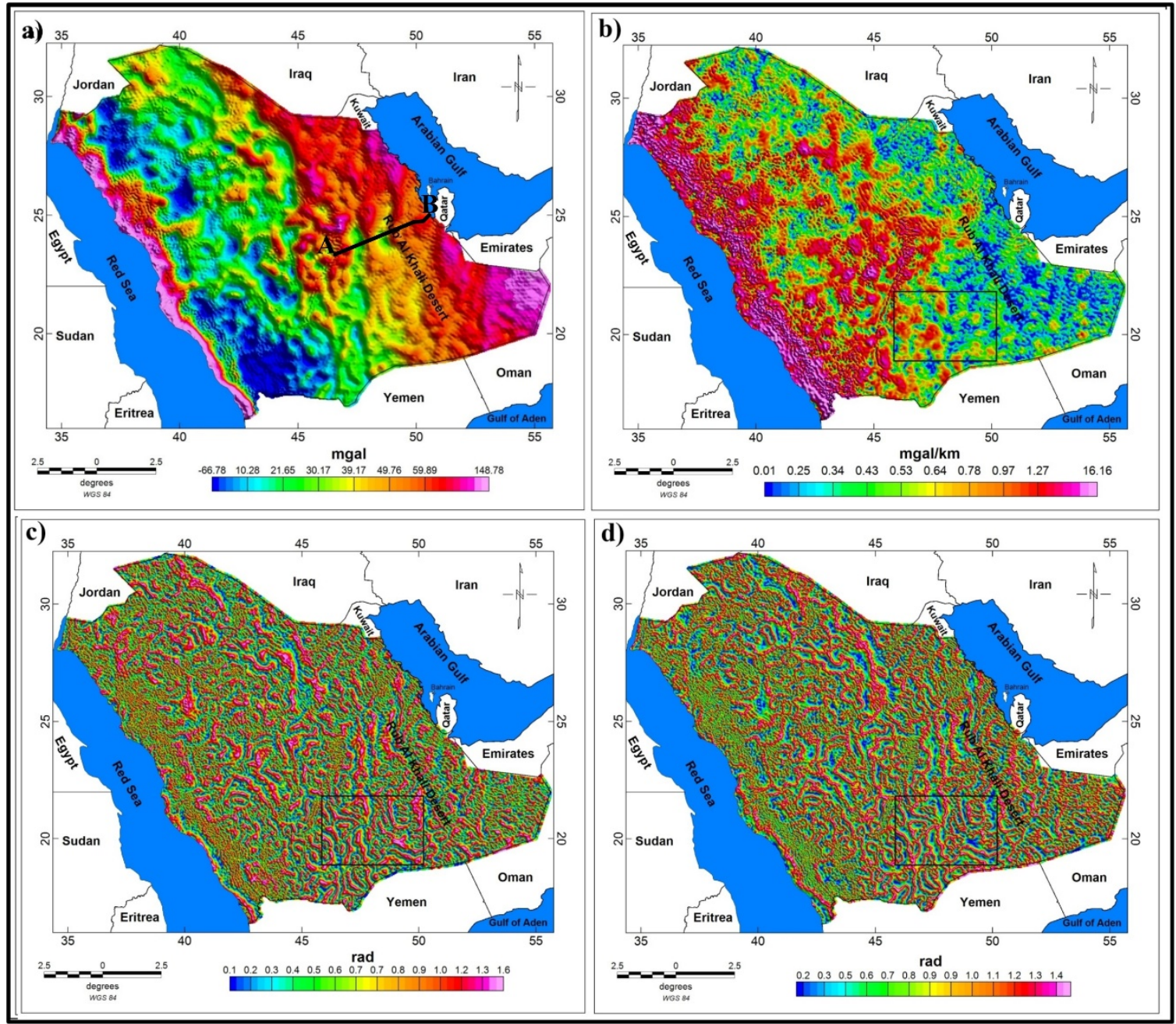

Figure 2. (a) Bouguer gravity anomaly map. (b) ASg map of the BG data. (c) TM of the BG data. (d) TDX map of the BG data of Saudi Arabia. 


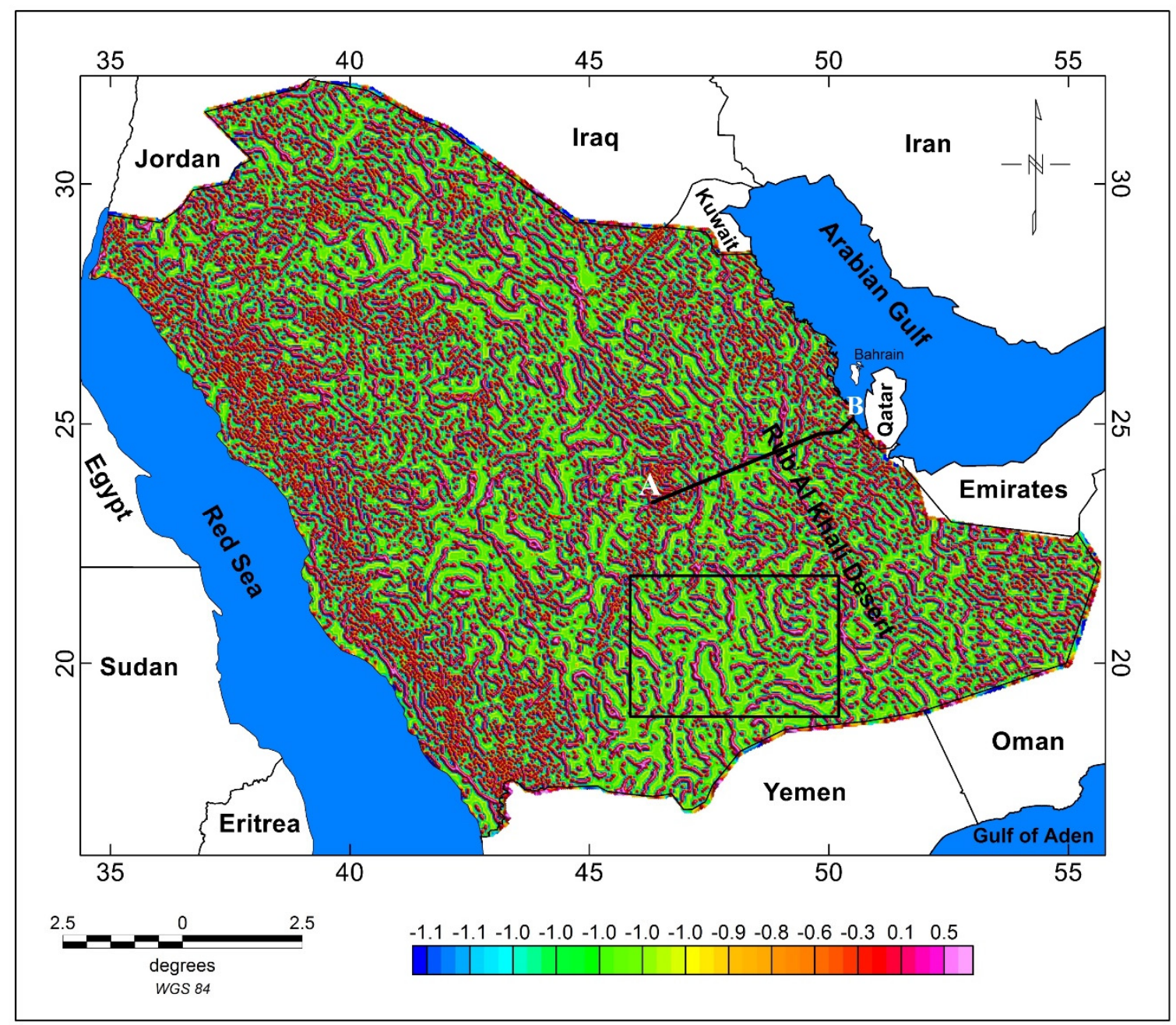

Figure 3. SF map of the BG data of Saudi Arabia.

The above-filtered maps contain numerous short lineaments, probably due to insignificant density bodies or noise in the data. Therefore, to map subsurface density boundaries of interest and suppress high-frequency anomalies, the BG data were upwardcontinued [74-78] (to altitudes of 2 and 4 km; Figures 6a and 8a, respectively). These upward-continued maps, in general, represent density boundaries 3 and $6 \mathrm{~km}$ below the Earth's surface [79]. Then the ASg, TM, TDX, and SF filters were applied to the upwardcontinued (UPC) data (Figures 4, 5, 6b-d and 7). The same general patterns are revealed in the up-continued filtered maps above (Figure $2 \mathrm{~b}-\mathrm{d}$ ). The ASg filter does not produce useful lineaments for deeper density boundaries. The TM and TDX filters created a series of lineaments, but numerous short lineaments made interpretation difficult. The longer lineaments generally agreed in location with both methods and the SF filter, but were not as highly resolved as the SF-generated lineaments (Figures 5 and 7). The SF filter maps (Figures 5 and 7) had some short lineaments, but mainly consisted of longer lineaments, even at $6 \mathrm{~km}$ depth. This made the interpretation of the lineaments easier. Most longer lineaments either trended N-S, especially in the southern and western portion of Saudi Arabia, or NW-SE elsewhere. These directions agree with the major fault system orientation or the trend of the suture zones (Figure 1). 

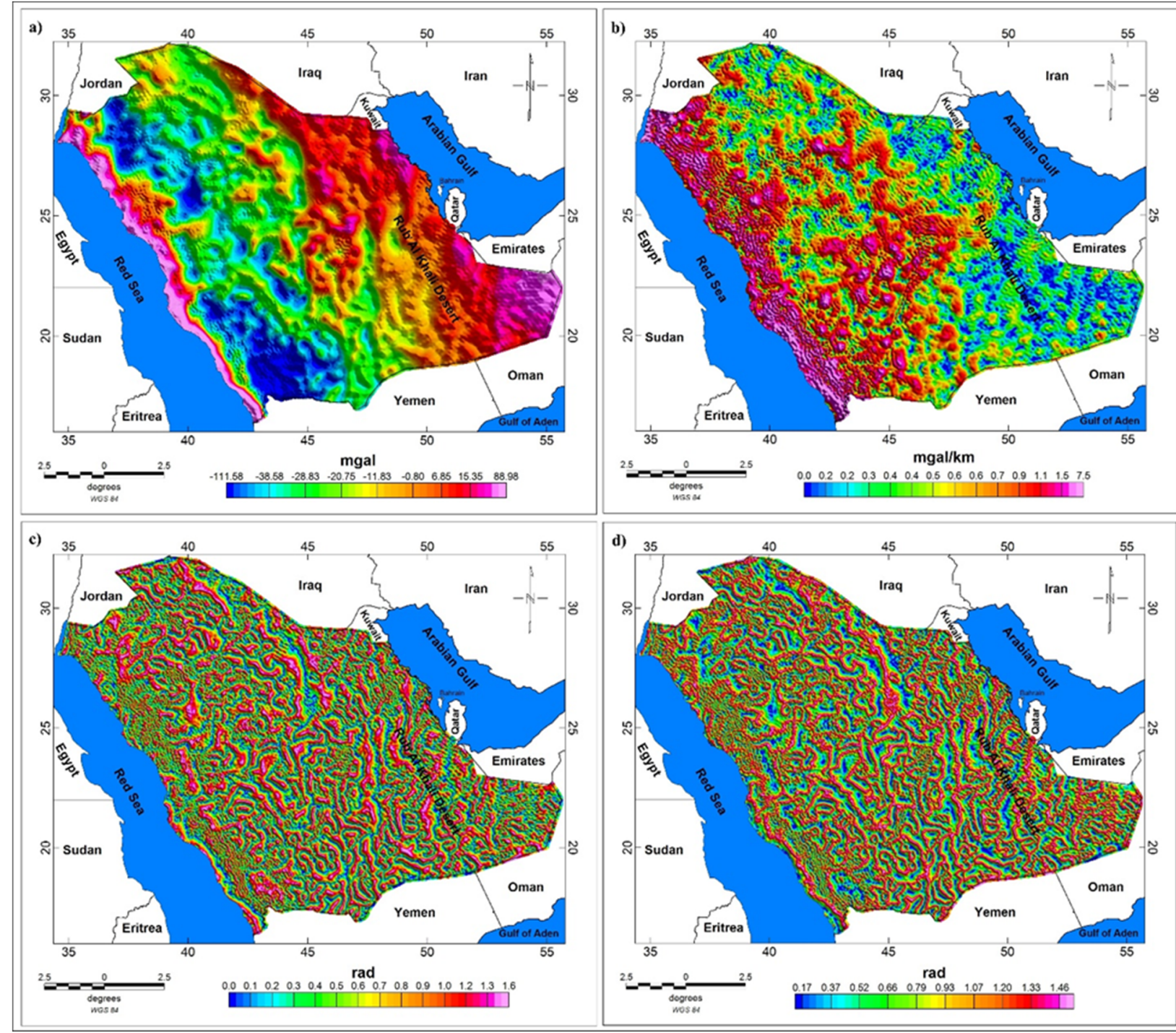

Figure 4. All maps show the BC data continued upward to $2 \mathrm{~km}$ above the Earths' surface: (a) UPC map; (b) ASg map; (c) TM; (d) TDX map. 


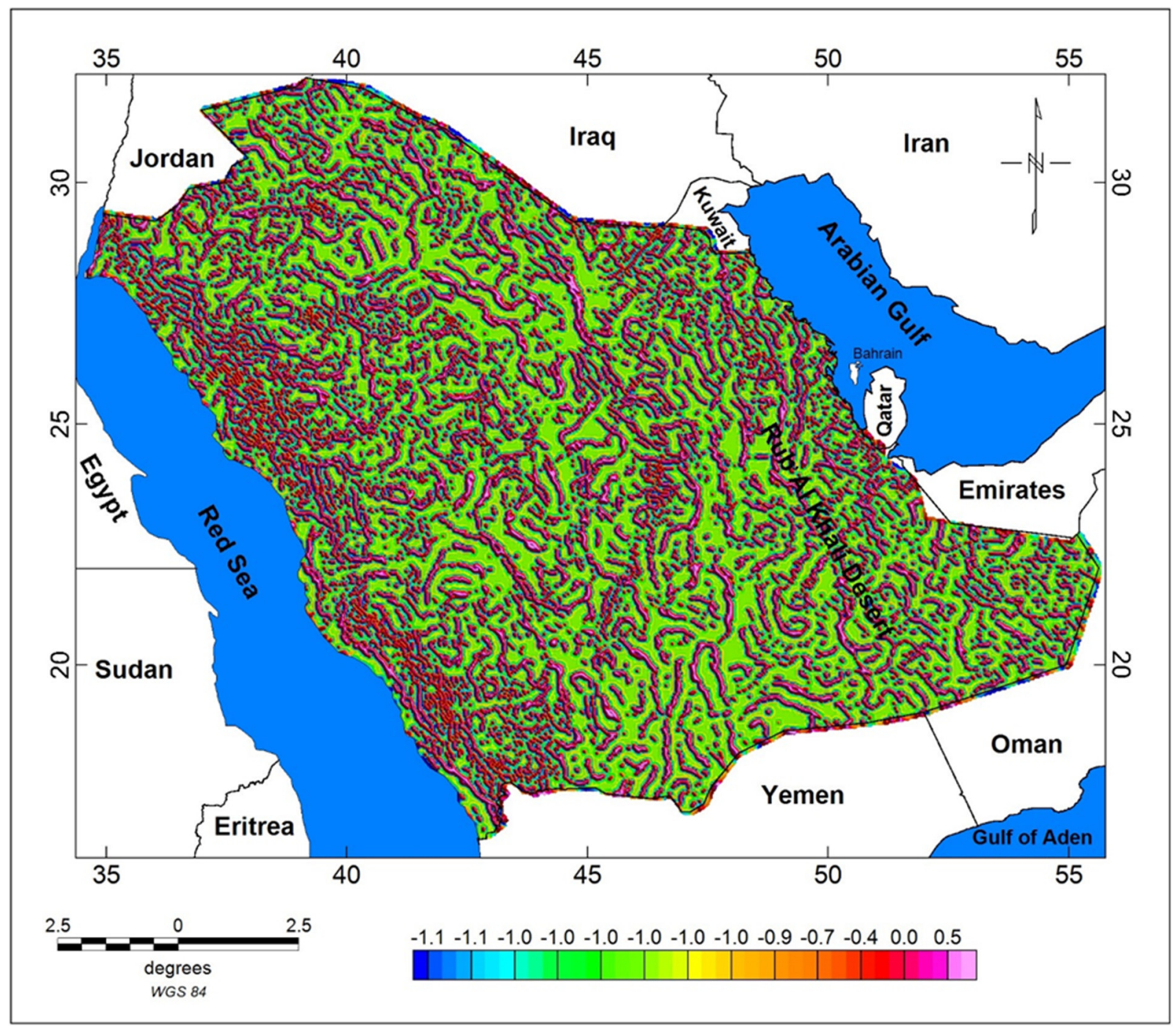

Figure 5. SF map of the $2 \mathrm{~km} \mathrm{UPC} \mathrm{data} \mathrm{of} \mathrm{Saudi} \mathrm{Arabia.}$ 


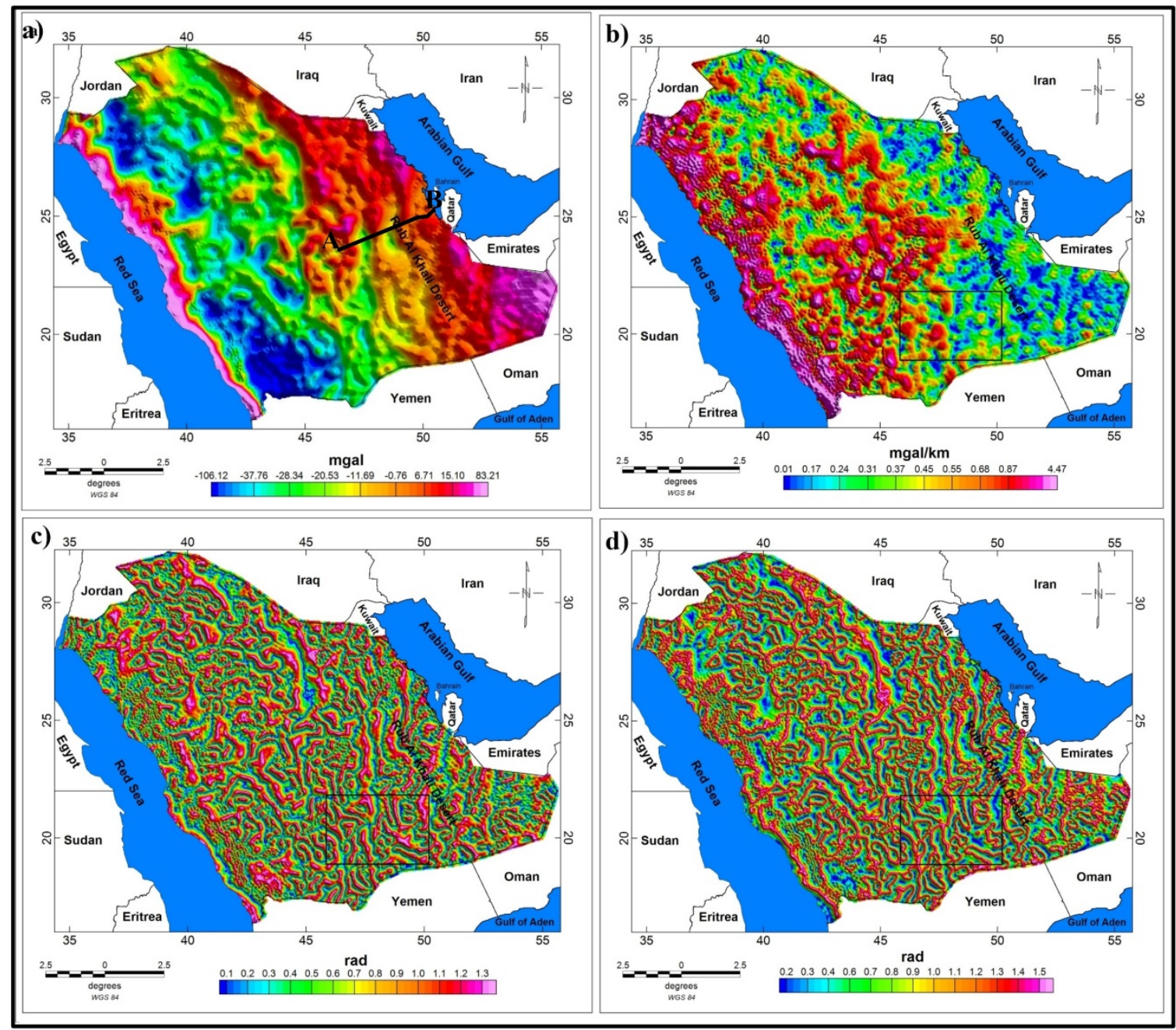

Figure 6. All maps show the BC data continued upward to $4 \mathrm{~km}$ above the Earths' surface: (a) UPC map; (b) ASg map; (c) TM map; (d) TDX map. 


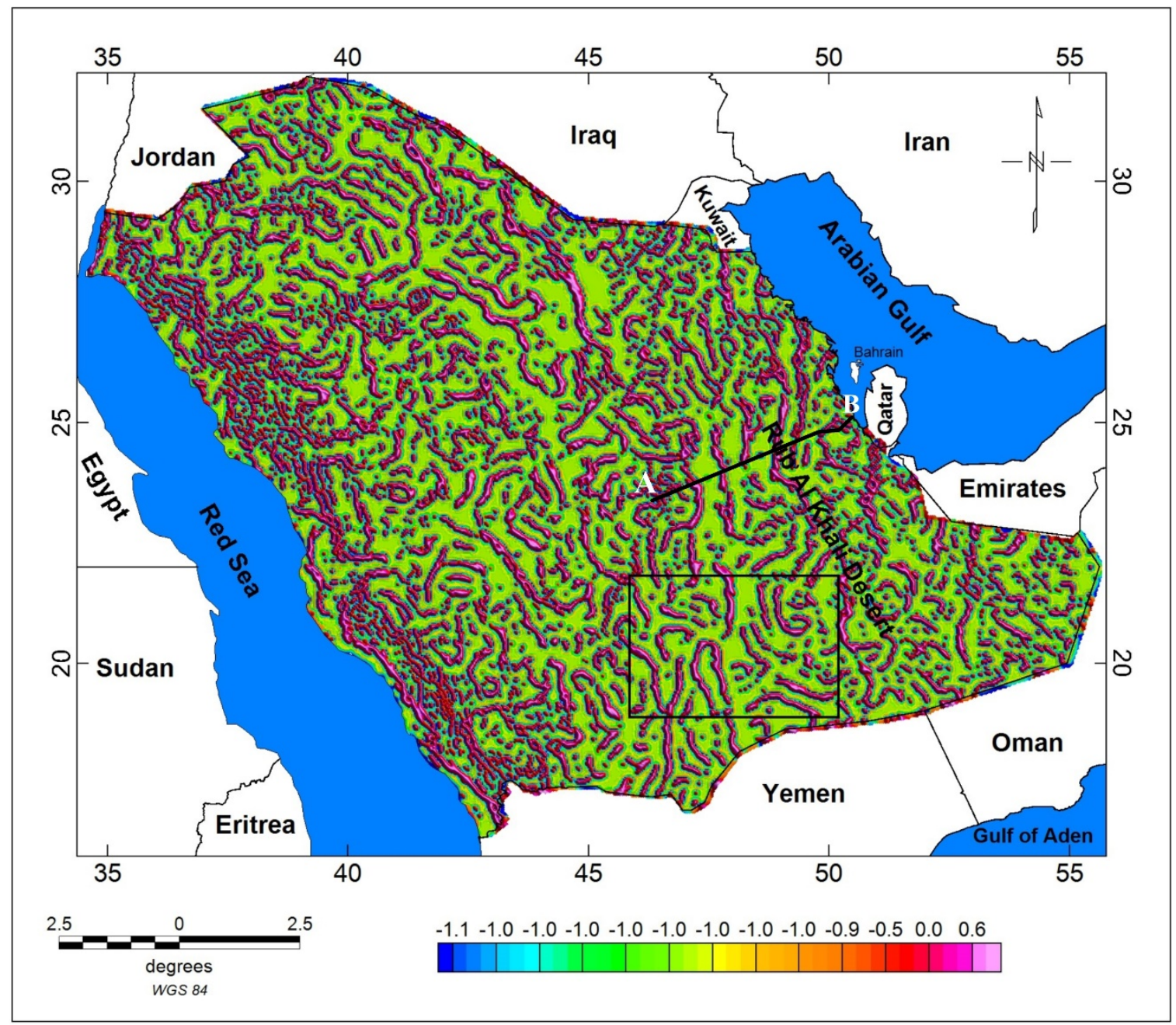

Figure 7. SF map of the $4 \mathrm{~km}$ UPC data of Saudi Arabia.

\section{Discussion}

\subsection{The Traced Lineament Inspection by Application of the Various Detectors}

The above discussion shows that the SF provided the best resolved or highest re-solved lineaments for both shallow and deeper density sources. To prove reliability, we compared the edges obtained from the SF filter with a geologic cross-section across the study area (Figure 8). We see a good correlation between geologic information and the images of the $\mathrm{SF}$, with many peaks indicating basement-reverse faults.

To emphasize how the SF filter generated easier-to-interpret and better-resolved lineaments due to deep density sources, a close-up of the anomalies from the BG and $4 \mathrm{~km} \mathrm{UPC}$ maps are shown (black rectangle) in Figures 2 and 3 and Figures 6 and 7 (Figure 9). The ASg filter does not accurately produce lineations and thus is hard to interpret (Figure 9a,e). The TM filter (Figure 9b,f) does produce lineations, but the width of the maxima is too wide to accurately determine the edge of either a shallow or deep source. Moreover, too many lineations merge into one another, making interpretation difficult. Although the TDX filter (Figure 9c,g) does a better job in producing distinct thin lineaments, they are still interconnected, thus producing false edges. Only the SF filter (Figure $9 \mathrm{~d}, \mathrm{~h}$ ) produces sharp and thin edges where the thinner edges are sharper. 


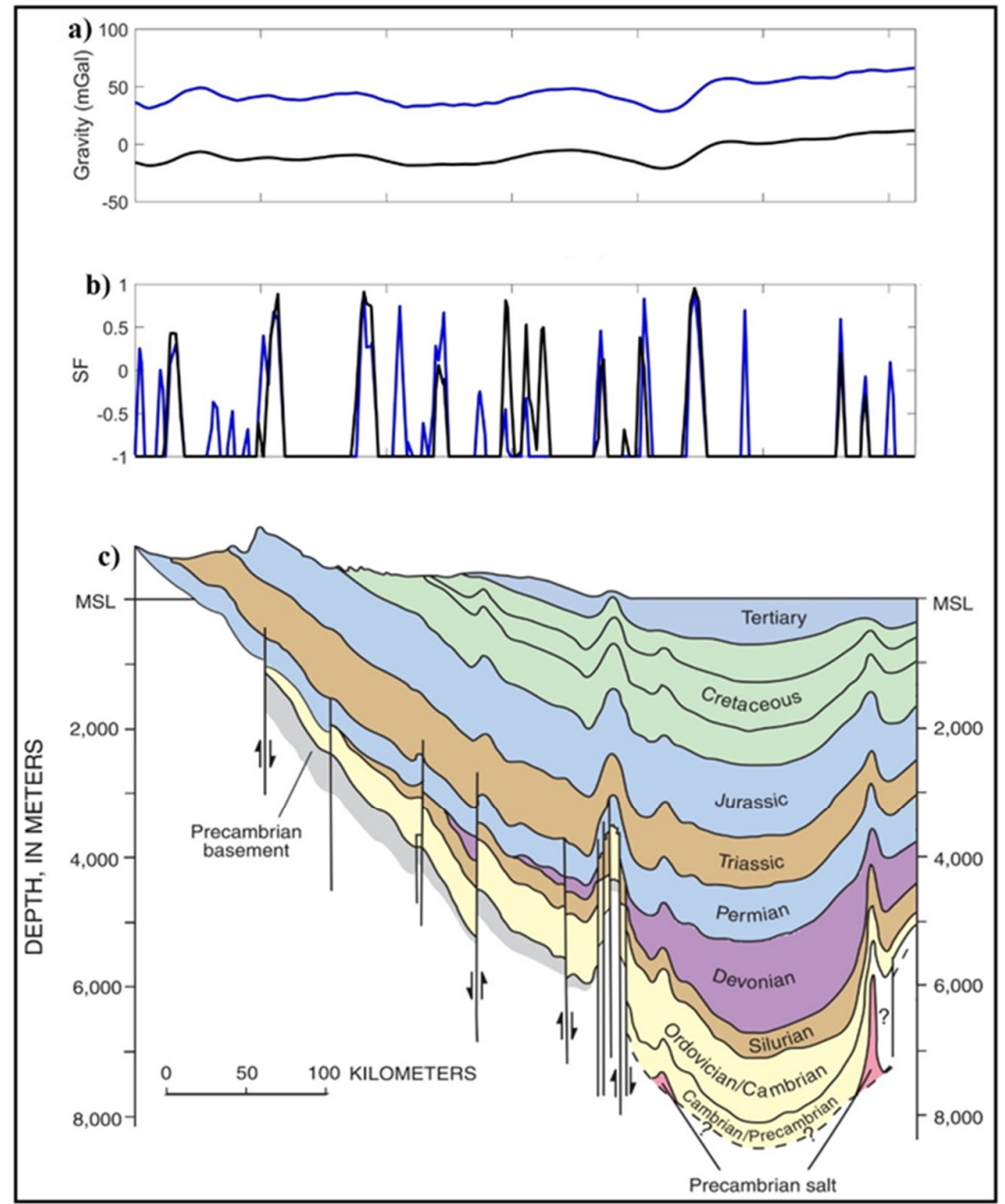

Figure 8. (a) Bouguer gravity data (blue line) and $4 \mathrm{~km}$ upward-continued Bouguer gravity data (black line) of profile AB shown in Figures 2a and 6a. (b) SF of Bouguer gravity data (blue line) and SF of upward-continued Bouguer gravity data (black line) of profile AB shown in Figures 3 and 7. (c) Geologic cross-section across the study area showing basement-reverse faults and Precambrian (Infracambrian) salt. Modified from [80-82].
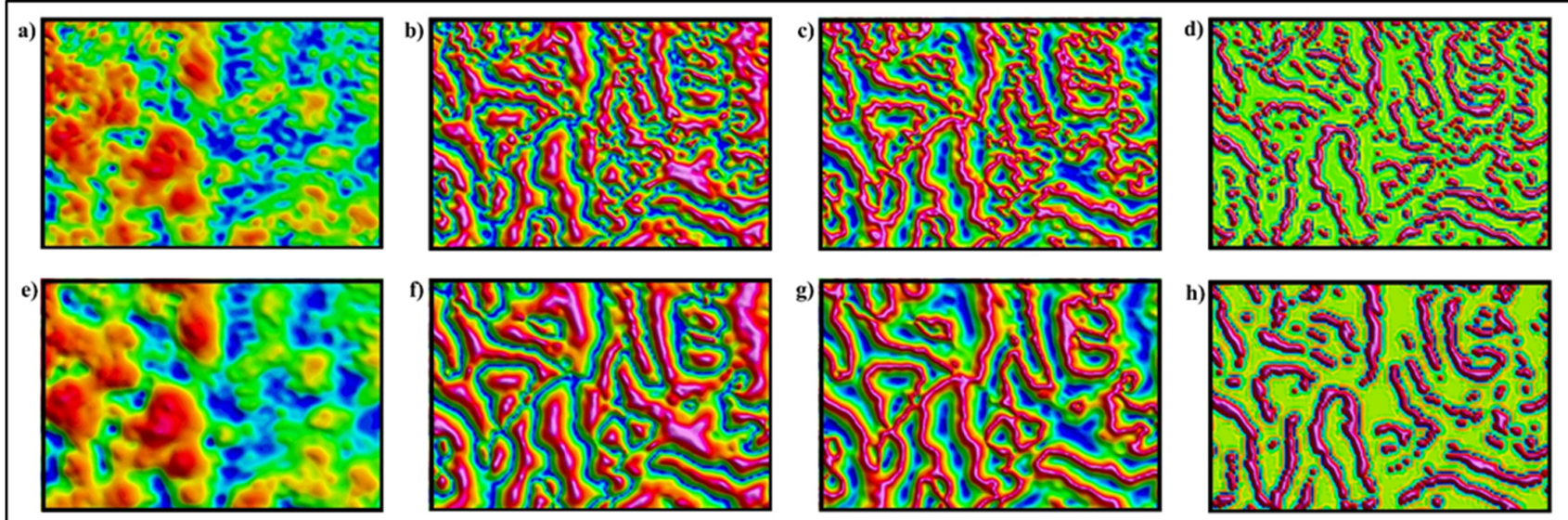

Figure 9. Filter anomalies of the region are highlighted in Figures 2, 3, 6 and 7: (a) ASg of BG (Figure 2b); (b) TM of BG (Figure 2c); (c) TDX of BG (Figure 2d); (d) SF of BG (Figure 3); (e) ASg of $4 \mathrm{~km} \mathrm{UPC} \mathrm{(Figure} \mathrm{6b);} \mathrm{(f)} \mathrm{TM} \mathrm{of} 4$ km UPC (Figure 6c); (g) TDX of 4 km UPC (Figure 6d); (h) SF of $4 \mathrm{~km}$ UPC (Figure 7). 
In order to emphasize the lineaments, we used ArcGIS algorithms to trace and delineate the structural lineaments on all BG and 4 km UPC-filtered maps. Figure 10 shows the maxima of the ASg, TM, and TDX filtered results (Figures 2 and 6); the orientations of these maxima are shown as rose diagrams. The ASg and ASg-4km UPC lineaments and rose diagrams (Figure 10a,d,g,j) cannot produce significant lineations from shallow or deep density bodies. This is especially true in the southeastern part of Saudi Arabia, where the ASg failed to detect density boundaries beneath the thick sedimentary cover. The blurred and wide maxima from the TM and TM-4km UPC maps produce lineaments, but the maxima lineaments are disconnected, making them hard to relate to regional structures (Figure 10b,e,h,k). The connected edges are reflected in the connectivity of the traced maxima lineaments from the TDX filter (Figure 10c,i). The rose diagrams of the TDX lineaments (Figure 10f,l) indicate a broad trend that does not agree with mapped structures within Saudi Arabia, indicating that the TDX filter generates false lineaments.

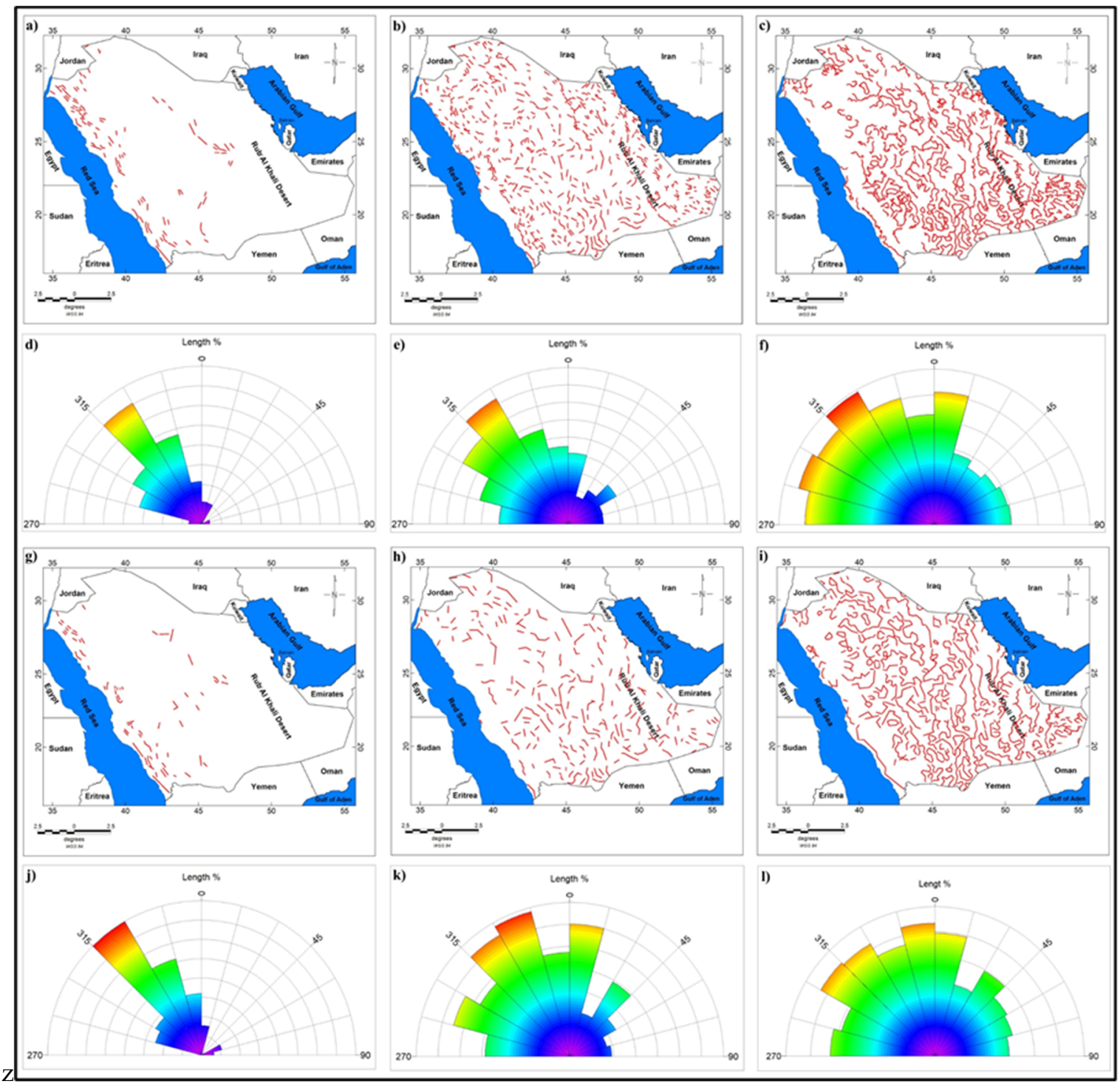

Figure 10. Lineament maps of the maxima anomalies using the BG data from the various filters: (a) ASg; (b) TM; (c) TDX, as well as Rose diagrams of the orientations of BG-generated lineaments: (d) ASg; (e) TM; (f) TDX. Lineament maps of the maxima anomalies using the $4 \mathrm{~km}$ UPC data from the various filters: (g) ASg; (h) TM; (i) TDX, as well as Rose diagrams of the orientations of the $4 \mathrm{~km}$ UPC-generated lineaments: (j) ASg; (k) TM; (l) TDX. 
Figure 11 shows the lineament and statistical analysis (rose diagrams) of the SF filters and the main structural features and Au deposits $[32,33,83]$. The SF results from the shallow and deeper density bodies are easier to interpret as they are more connected than the other filtered results. The rose diagrams additionally indicate trends of the lineaments that agree with the mapped structures of Saudi Arabia [32].

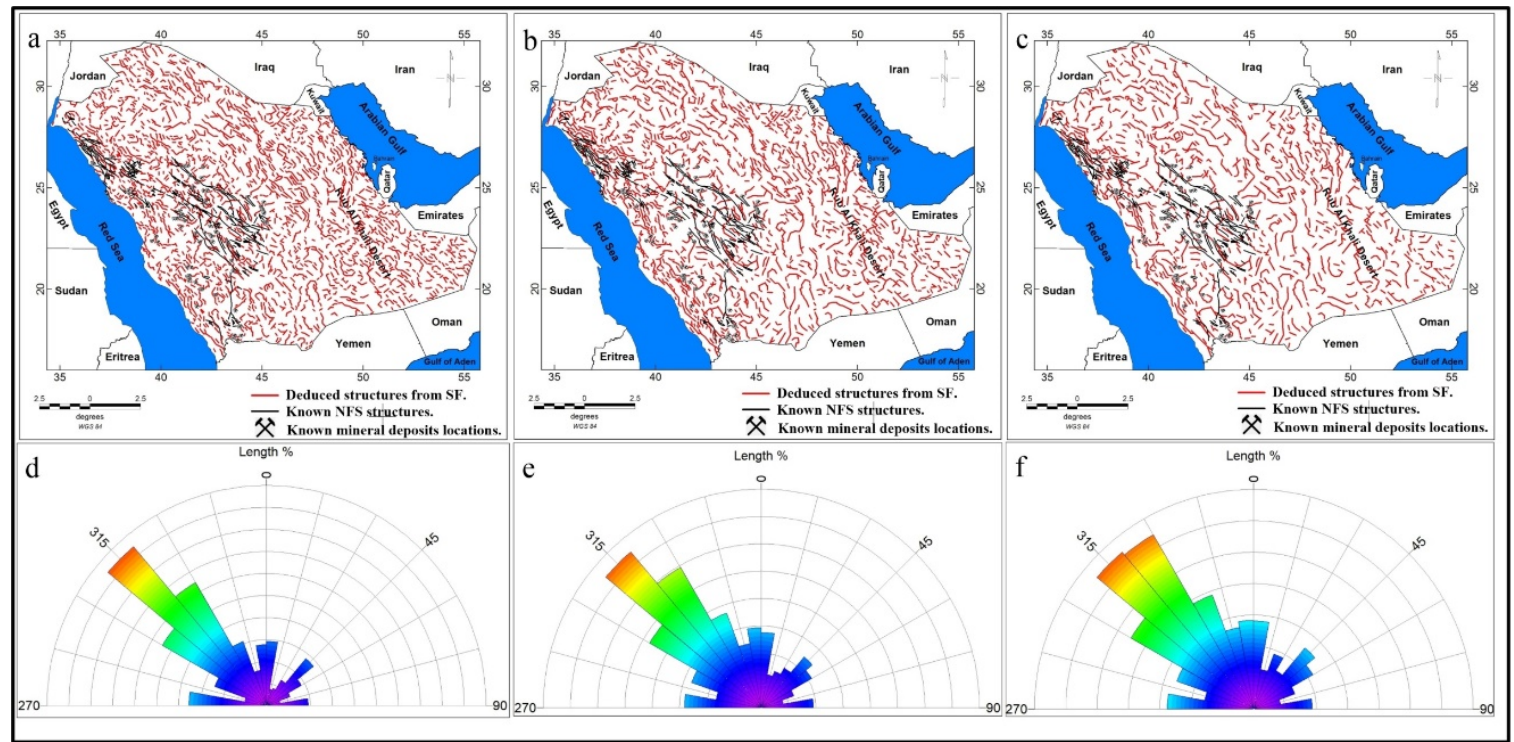

Figure 11. Lineaments from the SF filtered data: (a) BG; (b) $2 \mathrm{~km} \mathrm{UPC;} \mathrm{(c)} 4 \mathrm{~km} \mathrm{UPC}$, and rose diagrams of the orientations of the lineaments: (d) BG, (e) $2 \mathrm{~km} \mathrm{UPC}$, and (f) $4 \mathrm{~km} \mathrm{UPC}$.

Figure 3 showed that the SF method could sharply detect important structural features. The Najd fault system (NFS) can be delineated in near-parallel lines extending from the southeastern to the northwestern sides of Saudi Arabia. The boundary between the AS, Arabian Shelf, and another area [32,33] and references therein can be sharply detected. Moreover, the main sutures and shear zones separate the AS terranes. Multiple intersection zones and high, abrupt curvatures in the structures can be delineated from the SF map (Figure 3).

Geodynamically, the AS is one of the Earth's most significant megastructures [84]. Accordingly, the SF maps (Figures 3, 5 and 7) unveil the first tectonostructural map of Saudi Arabia (Figure 11). The structures, boundaries, and lineaments of Saudi Arabia are outlined and traced (Figure 11a-c) and statistically examined in rose diagrams (Figure 11d-f) for the SF-BG, SF-2 km UPC, and SF-4 km UPC results, respectively. These figures reveal that the NW to WNW trends have notable structures dominating the evolution of the AS and Arabian Shelf in Saudi Arabia. Based on the irregularities, the rheological and lateral abnormalities, multiple junctions, and tectonic characteristics of the gravity data (Figure 3), we can partition the AS of Saudi Arabia into tectonic terranes/territories (Figure 12). These subclasses harmonize well with the published subdivisions based on structural/field investigations and geological observations $[32,85]$. The Asir terrane is differentiated from the neighboring terranes (Jeddah and Afif) based on the distinguished curvature in the lineaments and boundaries (Figure 3). Figures 3 and 11 unveil that the Hijaz terrane is distinguished by the NW architectural style; WNW is dominant in the Ha'il terrane, while the NNW and NW trends affect the Afif terrane. The application of a sharp SF edge detector to gravity data outlined and interpreted the main tectonics well, and we were consequently able to produce a new structural map for all of Saudi Arabia. 


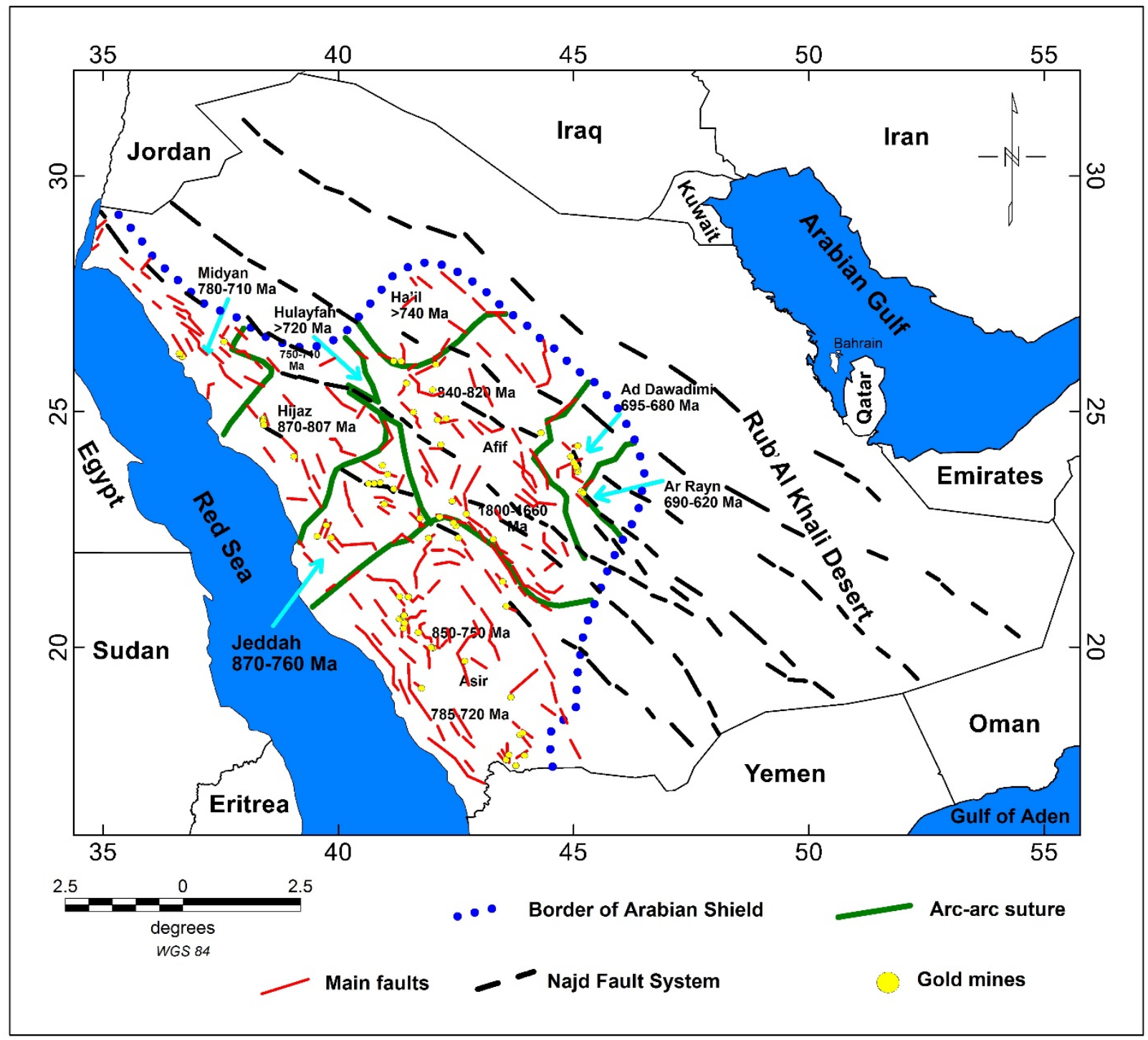

Figure 12. Interpreted tectostructural terranes of Saudi Arabia. Based on the analysis of the SF of gravity data $[32,33,83]$.

\subsection{The Relationship between the Main Structures and Au Mineralization}

Major Au deposits in Saudi Arabia are controlled by shear zones [86,87]. When superimposed onto the SF map (Figure 5), known mineralization sites linked to the NFS and major shear zones reflect the structurally controlled mineralization of Saudi Arabia. Au-related deformation events linked to ore genesis were distinct from high-level, brittle deformation typical of many epithermal deposits. Au-ore genesis is related to a high-level deformational event; these tectonic events accompanied significant fluid flows [88]. Tectonically, ANS Au mineralization is related to the deformational tectonothermal events active during the primitive stages of the island-arc formation. Pre-orogenic Au mineralization was formed by hot brines accompanying submarine volcanic activity [89].

Many orogenic Au deposits are controlled by shear zones and fault systems (Figure 11). The conjugate NFS with sinistral displacement in an NW direction (i.e., Qazaz, Ajjaj, Halaban-Zarghat, Ar Rika, and Ruwah fault zones) and dextral sense with a NE direction (i.e., Hanabiq, Al Amar, Ad Damm, and Nabitah fault zones) exist in limited zones relative to the total area of the Arabian Shield. There are numerous Au mines located outside the NFS zone, and, unexpectedly, the connectivity between the conjugate systems of the NFS decreases downward (Figure 11a-c). Additionally, the connectivity along the same fault zone decreases downward (Figure 11a-c), and the central zones in each fault zone become 
more significant with increasing depth. The potentiality of extensive Au mineralization increases above the central zones, confirmed by the location of large Au mines directly above the central zone, i.e., Fawarah, Gariat Avala, Hamdah, and Ghadarah. Therefore, the presence of small mines lacking structural controls at greater depths is related to disconnectivity with the fault's central zones (Figure 9a-c), which are the main feeding zones for Au mineralization, resulting from fluid circulation at greater depths.

Unexpectedly, major fault zones parallel to the Red Sea extend south to north; their connectivity increases downward and controls numerous Au mines, i.e., Jadmah, Wadi Bidah, Mamilah, and Wadi Leif. These fault zones intersect the NFS in the Midyan Terrane at the northern part of the AS, and their conjugation is a favorable area for Au mineralization at greater depth.

\section{Conclusions}

Economically, Saudi Arabia is one of the most essential regions of the world. Producing a new structural map for Saudi Arabia with structurally related mineralizations was the main target of our study. To achieve the results, we applied the ASg, TM, TDX, and SF methods to actual satellite BG data of Saudi Arabia. The SF filter applied to the gravity data of Saudi Arabia efficiently delineated the contacts and lineaments for both shallow and deep components of Saudi Arabia.

We produced new structural maps for BG and upward-continued data of Saudi Arabia by applying the accurate and sharp SF filter. The deduced structures from the SF filter were compared with structures from previous studies and known mineralized zones of Saudi Arabia. The results revealed that most of the known mineralization sites in Saudi Arabia are structurally controlled but not governed by the NFS. Most orogenic Au deposits were controlled by prominent and subsidiary shear zones. Au-related deformation events linked to ore genesis were distinct from high-level, brittle deformation typical of many epithermal deposits.

Finally, the SF filters were successfully employed to construct new deep and shallow tectonostructural maps of Saudi Arabia. These new tectonostructural maps were used to decipher the structural framework controlling the mineral deposits of Saudi Arabia.

Author Contributions: This work was made possible by notable contributions from all authors. A.M.E., R.A.Y.E.-Q., H.S., A.E.B. and L.T.P., Conceptualization, Methodology (Structures and magnetic), Data analysis, Investigation, and interpretation. A.M.E., R.A.Y.E.-Q., K.A. and M.S.A., Original Draft, Writing-Review \& editing the final MS, Visualization and presentation of geophysical data datasets. A.M.E. and K.M., Corresponding, Review \& editing the final MS. All authors contributed critically to the drafts and gave final approval for publication. All authors have read and agreed to the published version of the manuscript.

Funding: Project (number RSP-2021/351), King Saud University, Riyadh, Saudi Arabia.

Data Availability Statement: The data that support the findings of this study are available from the corresponding author upon reasonable request.

Acknowledgments: Sincere thanks and gratitude to the Researchers Supporting Project (number RSP-2021/351), King Saud University, Riyadh, Saudi Arabia, for funding this research article.

Conflicts of Interest: The authors declare no conflict of interest.

\section{References}

1. Darwish, M.; Butt, N. Mineral Resource Potential and Its Development in Saudi Arabia. J. King Abdulaziz Univ. Sci. 1996, 8, 107-120. [CrossRef]

2. Ministry of Planning KSA, 1985-1990; Fourth Development Plan: Riyadh, Saudi Arabia, 1985; pp. 167-184.

3. Kafadar, O. CURVGRAV-GUI: A graphical user interface to interpret gravity data using curvature technique. Earth Sci. Inform. 2017, 10, 525-537. [CrossRef]

4. Eldosouky, A.M.; Saada, S.A. Source edge detection (SED) of aeromagnetic data: Synthetic examples and a case study from Haimur area, south Eastern Desert, Egypt. Arab. J. Geosci. 2020, 13, 1-12. [CrossRef] 
5. Pham, L.T.; Oksum, E.; Vu, M.D.; Vo, Q.T.; Le-Viet, K.D.; Eldosouky, A.M. An improved approach for detecting ridge locations to interpret the potential feld data for more accurate structural mapping: A case study from Vredefort dome area (South Africa). J. Afr. Earth Sci. 2021, 175, 104099. [CrossRef]

6. Pham, L.T.; Kafadar, O.; Oksum, E.; Eldosouky, A.M. An improved approach for detecting the locations of the maxima in interpreting potential feld data. Arab. J. Geosci. 2021, 14, 43. [CrossRef]

7. Eldosouky, A.M.; Mohamed, H. Edge detection of aeromagnetic data as effective tools for structural imaging at Shilman area, South Eastern Desert, Egypt. Arab. J. Geosci. 2021, 14, 1-10. [CrossRef]

8. Eldosouky, A.M.; Abdelkareem, M.; Elkhateeb, S.O. Integration of remote sensing and aeromagnetic data for mapping structural features and hydrothermal alteration zones in Wadi Allaqi area, South Eastern Desert of Egypt. J. Afr. Earth Sci. 2017, 130, 28-37. [CrossRef]

9. Eldosouky, A.; Sehsah, H.; Elkhateeb, S.O.; Pour, A.B. Integrating aeromagnetic data and Landsat-8 imagery for detection of post-accretionary shear zones controlling hydrothermal alterations: The Allaqi-Heiani Suture zone, South Eastern Desert, Egypt. Adv. Space Res. 2020, 65, 1008-1024. [CrossRef]

10. Eldosouky, A.M.; El-Qassas, R.A.; Pour, A.B.; Mohamed, H.; Sekandari, M. Integration of ASTER satellite imagery and 3D inversion of aeromagnetic data for deep mineral exploration. Adv. Space Res. 2021, 68, 3641-3662. [CrossRef]

11. Oksum, E.; Le, D.V.; Vu, M.D.; Nguyen, T.H.T.; Pham, L.T. A novel approach based on the fast sigmoid function for interpretation of potential field data. Boll. Geofis. Teor. Appl. 2021, 10, 543-556. [CrossRef]

12. Elkhateeb, S.O.; Eldosouky, A.M.; Khalifa, M.O.; Aboalhassan, M. Probability of mineral occurrence in the Southeast of Aswan area, Egypt, from the analysis of aeromagnetic data. Arab. J. Geosci. 2021, 14, 1-12. [CrossRef]

13. Pham, L.T. A comparative study on different filters for enhancing potential field source boundaries: Synthetic examples and a case study from the Song Hong Trough (Vietnam). Arab. J. Geosci. 2020, 13, 1-10. [CrossRef]

14. Pham, L.T. A high resolution edge detector for interpreting potential field data: A case study from the Witwatersrand basin, South Africa. J. Afr. Earth Sci. 2021, 178, 104190. [CrossRef]

15. Evjen, H.M. The place of the vertical gradient in gravitational interpretations. Geophysics 1936, 1, 127-136. [CrossRef]

16. Cordell, L.; Grauch, V.J.S. Mapping Basement Magnetization Zones from Aeromagnetic Data in the San Juan Basin, New Mexico, in The Utility of Regional Gravity and Magnetic Maps, 1st ed.; Hinze, W.J., Ed.; Society of Exploration Geophysicists: Tulsa, OK, USA, 1985; pp. 181-197.

17. Roest, W.; Verhoef, J.; Pilkington, M. Magnetic interpretation using the 3-D analytic signal. Geophysics 1992, 57, 116-125. [CrossRef]

18. Beiki, M. Analytic signals of gravity gradient tensor and their application to estimate source location. Geophysics 2010, 75, I59-I74. [CrossRef]

19. Pham, L.T.; Eldosouky, A.M.; Oksum, E.; Saada, S.A. A new high resolution filter for source edge detection of potential field data. Geocarto Int. 2020, 1-18. [CrossRef]

20. Pham, L.T.; Van Vu, T.; Le Thi, S.; Trinh, P.T. Enhancement of Potential Field Source Boundaries Using an Improved Logistic Filter. Pure Appl. Geophys. 2020, 177, 5237-5249. [CrossRef]

21. Miller, H.G.; Singh, V. Potential field tilt-A new concept for location of potential field sources. J. Appl. Geophys. 1994, 32, 213-217. [CrossRef]

22. Wijns, C.; Perez, C.; Kowalczyk, P. Theta map: Edge detection in magnetic data. Geophysics 2005, 70, L39-L43. [CrossRef]

23. Cooper, G.; Cowan, D. Enhancing potential field data using filters based on the local phase. Comput. Geosci. 2006, 32, 1585-1591. [CrossRef]

24. Pham, L.T.; Oksum, E.; Do, T.D.; Nguyen, D.V.; Eldosouky, A.M. On the performance of phase-based filters for enhancing lateral boundaries of magnetic and gravity sources: A case study of the Seattle uplift. Arab. J. Geosci. 2021, 14, 1-11. [CrossRef]

25. Pham, L.T.; Vu, M.D.; Le, S.T. Performance Evaluation of Amplitude- and Phase-Based Methods for Estimating Edges of Potential Field Sources. Iran. J. Sci. Technol. Trans. A Sci. 2021, 45, 1327-1339. [CrossRef]

26. Ferreira, F.J.F.; de Souza, J.; de Bongiolo, A.B.e.S.; de Castro, L.G. Enhancement of the total horizontal gradient of magnetic anomalies using the tilt angle. Geophysics 2013, 78, J33-J41. [CrossRef]

27. Pham, L.T.; Nguyen, D.A.; Eldosouky, A.M.; Abdelrahman, K.; Van Vu, T.; Al-Otaibi, N.; Ibrahim, E.; Kharbish, S. Subsurface structural mapping from high-resolution gravity data using advanced processing methods. J. King Saud Univ. Sci. 2021, 33, 101488. [CrossRef]

28. Melouah, O.; Pham, L.T. An improved ILTHG method for edge enhancement of geological structures: Application to gravity data from the Oued Righ valley. J. Afr. Earth Sci. 2021, 177, 104162. [CrossRef]

29. Pham, L.T.; Oksum, E.; Van Le, D.; Ferreira, F.J.F.; Le, S.T. Edge detection of potential field sources using the softsign function. Geocarto Int. 2021, 1-14. [CrossRef]

30. Al-Refeai, T.; Al-Ghamdy, D. Geological and geotechnical aspects of Saudi Arabia. Geotech. Geol. Eng. 1994, 12, $253-276$. [CrossRef]

31. Johnson, P.R. Proterozoic Geology of Western Saudi Arabia-Southern Sheet, Saudi Geological Survey, Open-File Report USGS-OF-99-7. 2000.

32. Stern, R.J.; Johnson, P. Continental lithosphere of the Arabian Plate: A geologic, petrologic, and geophysical synthesis. Earth-Sci. Rev. 2010, 101, 29-67. [CrossRef] 
33. Fritz, H.; Abdelsalam, M.; Ali, K.; Bingen, B.; Collins, A.; Fowler, A.; Ghebreab, W.; Hauzenberger, C.; Johnson, P.; Kusky, T.; et al. Orogen styles in the East African Orogen: A review of the Neoproterozoic to Cambrian tectonic evolution. J. Afr. Earth Sci. 2013, 86, 65-106. [CrossRef]

34. Laboun, A.A. The Paleozoic Geology of Saudi Arabia: History, Tectono-Stratigraphy, Glaciations, and Natural Resources. In The Structural Geology Contribution to the Africa-Eurasia Geology: Basement and Reservoir Structure, Ore Mineralisation and Tectonic Modellin; Springer: Berlin/Heidelberg, Germany, 2019; pp. 99-103.

35. Powers, R.W. Lexique Stratigraphic International-Saudi Arabia. 2010. Available online: http:/ / paleopolis.rediris.es/LEXICON/ KSA/Plate_01.htm (accessed on 27 March 2014).

36. Sahin, A. Mineral resources for in-situ carbonation of $\mathrm{CO}_{2}$ in the Arabian Shield. Int. J. Glob. Warm. 2016, 9, 275. [CrossRef]

37. Johnson, P.; Andresen, A.; Collins, A.; Fowler, A.; Fritz, H.; Ghebreab, W.; Kusky, T.; Stern, R. Late Cryogenian-Ediacaran history of the Arabian-Nubian Shield: A review of depositional, plutonic, structural, and tectonic events in the closing stages of the northern East African Orogen. J. Afr. Earth Sci. 2011, 61, 167-232. [CrossRef]

38. Robinson, F.A.; Bonin, B.; Pease, V.; Anderson, J.L. A discussion on the tectonic implications of Ediacaran late-to post-orogenic A-type granite in the northeastern Arabian Shield, Saudi Arabia. Tectonics 2017, 36, 582-600. [CrossRef]

39. Stern, R.J. The Najd Fault System, Saudi Arabia and Egypt: A Late Precambrian rift-related transform system? Tectonics 1985, 4, 497-511. [CrossRef]

40. Meyer, S.E.; Passchier, C.; Abu-Alam, T.; Stüwe, K. A strike-slip core complex from the Najd fault system, Arabian shield. Terra Nova 2014, 26, 387-394. [CrossRef]

41. Brown, G.F. Eastern margin of the Red Sea and the coastal structures in Saudi Arabia. Philos. Trans. R. Soc. Lond. A 1970, 267, 75-87.

42. Stewart, S.A. Structural geology of the Rub' Al-Khali Basin, Saudi Arabia. Tectonics 2016, 35, 2417-2438. [CrossRef]

43. Rodgers, A.J.; Walter, W.R.; Mellors, R.J.; Al-Amri, A.M.S.; Zhang, Y.-S. Lithospheric structure of the Arabian Shield and Platform from complete regional waveform modelling and surface wave group velocities. Geophys. J. Int. 1999, 138, 871-878. [CrossRef]

44. Al-Damegh, K.; Sandvol, E.; Barazangi, M. Crustal structure of the Arabian plate: New constraints from the analysis of teleseismic receiver functions. Earth Planet. Sci. Lett. 2005, 231, 177-196. [CrossRef]

45. Abdelsalam, M.G.; Abdeen, M.M.; Dowaidar, H.M.; Stern, R.J.; Abdelghaffar, A.A. Structural evolution of the Neoproterozoic Western Allaqi-Heiani suture, southeastern Egypt. Precambrian Res. 2003, 124, 87-104. [CrossRef]

46. Ali, K.; Azer, M.; Gahlan, H.; Wilde, S.; Samuel, M.; Stern, R. Age constraints on the formation and emplacement of Neoproterozoic ophiolites along the Allaqi-Heiani Suture, South Eastern Desert of Egypt. Gondwana Res. 2010, 18, 583-595. [CrossRef]

47. Abdelsalam, M.G. Quantifying 3D post-accretionary tectonic strain in the Arabian-Nubian Shield: Superimposition of the Oko Shear Zone on the Nakasib Suture, Red Sea Hills, Sudan. J. Afr. Earth Sci. 2010, 56, 167-178. [CrossRef]

48. Abdelsalam, M.G.; Stern, R.J. Structure of the late Proterozoic Nakasib suture, Sudan. J. Geol. Soc. 1993, 150, 1065-1074. [CrossRef]

49. Abdelsalam, M.G.; Stern, R.J. Mapping Precambrian structures in the Sahara Desert with SIR-C/X-SAR radar: The Neoproterozoic Keraf Suture, NE Sudan. J. Geophys. Res. Space Phys. 1996, 101, 23063-23076. [CrossRef]

50. Bailo, T.; Schandelmeier, H.; Franz, G.; Sun, C.-H.; Stern, R. Plutonic and metamorphic rocks from the Keraf Suture (NE Sudan): A glimpse of Neoproterozoic tectonic evolution on the NE margin of W. Gondwana. Precambrian Res. 2003, 123, 67-80. [CrossRef]

51. Surour, A.A.; Harbi, H.M.; Ahmed, A.H. The Bi'r Tawilah deposit, central western Saudi Arabia: Supergene enrichment of a Pan-African epithermal gold mineralization. J. Afr. Earth Sci. 2014, 89, 149-163. [CrossRef]

52. Johnson, P.; Zoheir, B.; Ghebreab, W.; Stern, R.; Barrie, C.; Hamer, R. Gold-bearing volcanogenic massive sulfides and orogenicgold deposits in the Nubian Shield. S. Afr. J. Geol. 2017, 120, 63-76. [CrossRef]

53. Al-Shanti, A.M.S. Geology of the Arabian Shield; Center for Scientific Publishing, King Abdlaziz University: Jeddah, Saudi Arabia, 1993.

54. Doebrich, J.L.; Zahony, S.G.; Leavitt, J.D.; Portacio, J.S., Jr.; Siddiqui, A.A.; Wooden, J.L.; Fleck, R.J.; Stein, H.J. Ad Duwayhi, Saudi Arabia: Geology and geochronology of a Neoproterozoic intrusion-related gold system in the Arabian Shield. Econ. Geol. 2004, 99, 713-741. [CrossRef]

55. Harbi, H.A.; Eldougdoug, A.A.; Al Jahdali, N.S. Evolution of the Arabian shield and associated mineralization. In Proceedings of the 9th Arab Conference of Mineral Resources, Jeddah, Saudi Arabia, 30 October-1 November 2006; pp. 1-11.

56. Goldfarb, R.; Groves, D.; Gardoll, S. Orogenic gold and geologic time: A global synthesis. Ore Geol. Rev. 2001, 18, 1-75. [CrossRef]

57. Alessio, B.L.; Blades, M.L.; Murray, G.; Thorpe, B.; Collins, A.S.; Kelsey, D.E.; Foden, J.; Payne, J.; Al-Khirbash, S.; Jourdan, F. Origin and tectonic evolution of the NE basement of Oman: A window into the Neoproterozoic accretionary growth of India? Geol. Mag. 2017, 155, 1150-1174. [CrossRef]

58. Johnson, P.; Abdelsalam, M.; Stern, R. The Bi'r Umq-Nakasib Suture Zone in the Arabian-Nubian Shield: A Key to Understanding Crustal Growth in the East African Orogen. Gondwana Res. 2003, 6, 523-530. [CrossRef]

59. Stern, R.J.; Abdelsalam, M.G. Formation of juvenile continental crust in the Arabian-Nubian shield: Evidence from granitic rocks of the Nakasib suture, NE Sudan. Acta Diabetol. 1998, 87, 150-160. [CrossRef]

60. Stern, R.J.; Kröner, A. Late Precambrian Crustal Evolution in NE Sudan: Isotopic and Geochronologic Constraints. J. Geol. 1993, 101, 555-574. [CrossRef]

61. Abdelsalam, M.G.; Stern, R.J.; Copeland, P.; Elfaki, E.M.; Elhur, B.; Ibrahim, F.M. The Neoproterozoic Keraf Suture in Ne Sudan: Sinistral Transpression Along the Eastern Margin of West Gondwana. J. Geol. 1998, 106, 133-148. [CrossRef] 
62. Hamimi, Z.; Fowler, A.-R. Najd Shear System in the Arabian-Nubian Shield. In The Geology of the Arabian-Nubian Shield; Springer Science and Business Media LLC: Berlin/Heidelberg, Germany, 2021; pp. 359-392.

63. Bonavia, F.F.; Chorowicz, J. Neoproterozoic structures in the Mozambique orogenic belt of south Ethiopia. Precambrian Res. 1993, 62, 307-322. [CrossRef]

64. Moore, J.M.c.M. Tectonics of the Najd transcurrent fault system, Saudi Arabia. J. Geol. Soc. 1979, 136, 441-453. [CrossRef]

65. Zoheir, B.A.; Johnson, P.R.; Goldfarb, R.J.; Klemm, D.D. Orogenic gold in the Egyptian Eastern Desert: Widespread gold mineralization in the late stages of Neoproterozoic orogeny. Gondwana Res. 2019, 75, 184-217. [CrossRef]

66. Eldosouky, A.M.; Pham, L.T.; Mohmed, H.; Pradhan, B. A comparative study of THG, AS, TA, Theta, TDX and LTHG techniques for improving source boundaries detection of magnetic data using synthetic models: A case study from G. Um Monqul, North Eastern Desert, Egypt. J. Afr. Earth Sci. 2020, 170, 103940. [CrossRef]

67. Sultan, M.; Wagdy, A.; Manocha, N.; Sauck, W.; Gelil, K.A.; Youssef, A.; Becker, R.; Milewski, A.; El Alfy, Z.; Jones, C. An integrated approach for identifying aquifers in transcurrent fault systems: The Najd shear system of the Arabian Nubian shield. $J$. Hydrol. 2008, 349, 475-488. [CrossRef]

68. Almadani, S.; Ibrahim, E.; Al-Amri, A.; Fnais, M.; Abdelrahman, K. Delineation of a fractured granite aquifer in the Alwadeen area, Southwest Saudi Arabia using a geoelectrical resistivity survey. Arab. J. Geosci. 2019, 12, 1-13. [CrossRef]

69. Pham, L.T.; Oksum, E.; Do, T.D. Edge enhancement of potential field data using the logistic function and the total horizontal gradient. Acta Geod. Geophys. 2019, 54, 143-155. [CrossRef]

70. Yao, Y.; Huang, D.; Yu, X.; Chai, B. Edge interpretation of potential field data with the normalized enhanced analytic signal. Acta Geod. Geophys. 2015, 51, 125-136. [CrossRef]

71. Förste, C.; Bruinsma, S.; Abrikosov, O.; Lemoine, J.-M.; Marty, J.C.; Flechtner, F.; Balmino, G.; Barthelmes, F.; Biancale, R. EIGEN-6C4 The latest combined global gravity field model including GOCE data up to degree and order 2190 of GFZ Potsdam and GRGS Toulouse. GFZ Data Serv. 2014. [CrossRef]

72. Pal, S.K.; Narayan, S.; Majumdar, T.J.; Kumar, U. Structural mapping over the $85^{\circ} \mathrm{E}$ Ridge and surroundings using EIGEN6C4 high-resolution global combined gravity field model: An integrated approach. Mar. Geophys. Res. 2016, 37, 159-184. [CrossRef]

73. Melouah, O.; Eldosouky, A.M.; Ebong, W.D. Crustal architecture, heat transfer modes and geothermal energy potentials of the Algerian Triassic provinces. Geothermics 2021, 96, 102211. [CrossRef]

74. Dean, W.C. Frequency analysis for gravity and magnetic interpretation. Geophysics 1958, 23, 97-127. [CrossRef]

75. Ravat, D.; Whaler, K.A.; Pilkington, M.; Sabaka, T.; Purucker, M. Compatibility of high-altitude aeromagnetic and satellite-altitude magnetic anomalies over Canada. Geophysics 2002, 67, 546-554. [CrossRef]

76. Eldosouky, A.M.; Elkhateeb, S.O. Texture analysis of aeromagnetic data for enhancing geologic features using co-occurrence matrices in Elallaqi area, South Eastern Desert of Egypt. NRIAG J. Astron. Geophys. 2018, 7, 155-161. [CrossRef]

77. Sehsah, H.; Eldosouky, A.M.; El Afandy, A.H. Unpaired ophiolite belts in the Neoproterozoic Allaqi-Heiani Suture, the ArabianNubian Shield: Evidences from magnetic data. J. Afr. Earth Sci. 2019, 156, 26-34. [CrossRef]

78. Eldosouky, A.M. Aeromagnetic data for mapping geologic contacts at Samr El-Qaa area, North Eastern Desert, Egypt. Arab. J. Geosci. 2019, 12, 1-13. [CrossRef]

79. Jacobsen, B.H. A Case for Upward Continuation as a Standard Separation Filter for Potential-Field Maps. Geophysics 1987, 52, 390-398. [CrossRef]

80. Alsharhan, A.S.; Nairn, A.E.M. Sedimentary Basins and Petroleum Geology of the Middle East; Elsevier: Amsterdam, The Netherlands, 1997; p. 942.

81. Konert, G.; Afifi, A.M.; Al-Hajri, S.A.; Droste, H.J. Paleozoic stratigraphy and hydrocarbon habitat of the Arabian Plate. GeoArabia 2001, 6, 407-442.

82. Pollastro, R.M. Total Petroleum Systems of the Paleozoic and Jurassic, Greater Ghawar Uplift and Adjoining Provinces of Central Saudi Arabia and Northern Arabian-Persian Gulf, No. 2202-H of Geological Survey Bulletin; U.S. Geological Survey: Reston, VA, USA, 2003.

83. Eldosouky, A.M.; Pham, L.T.; El-Qassas, R.A.Y.; Hamimi, Z.; Oksum, E. Lithospheric Structure of the Arabian-Nubian Shield Using Satellite Potential Field Data. In The Geology of the Arabian-Nubian Shield; Springer: Berlin/Heidelberg, Germany, 2021; pp. 139-151. [CrossRef]

84. Robertson, A. Development of concepts concerning the genesis and emplacement of Tethyan ophiolites in the Eastern Mediterranean and Oman regions. Earth-Sci. Rev. 2004, 66, 331-387. [CrossRef]

85. Berhe, S.M. Ophiolites in Northeast and East Africa: Implications for Proterozoic crustal growth. J. Geol. Soc. 1990, 147, 41-57. [CrossRef]

86. Roberts, R.G. Archean lode gold deposits. Geosci. Can. 1987, 1, 1-19.

87. Bonnemaison, M.; Marcoux, E. Auriferous mineralization in some shear-zones: A three-stage model of metallogenesis. Miner. Depos. 1990, 25, 96-104. [CrossRef]

88. Peters, S.G. Syn-deformational features of Carlin-type Au deposits. J. Struct. Geol. 2004, 26, 1007-1023. [CrossRef]

89. Botros, N. The role of the granite emplacement and structural setting on the genesis of gold mineralization in Egypt. Ore Geol. Rev. 2015, 70, 173-187. [CrossRef] 